\title{
EXPOSURE TO DOMESTIC VIOLENCE DURING PREGNANCY: PERCEPTIONS AND COPING MECHANISMS OF A VULNERABLE GROUP
}

\author{
Ms E Libuku \\ MNSc \\ Post-graduate student, Department of Nursing Science, University of Namibia
}

\section{Prof. LF Small}

DNSc

Associate Professor, Department of Nursing Science, University of Namibia

Corresponding author: loui3@iway.co.za

\section{Ms W Wilkinson \\ MSocSc \\ Lecturer, Department of Nursing Science, University of Namibia}

Keywords: domestic violence; health belief model; coping mechanisms; belief systems; vulnerable groups

\begin{abstract}
The purpose of this study was to explore and describe the perceptions of maternity clients' relating to domestic violence. A quantitative, exploratory and descriptive design was utilised. The population consisted of maternity patients admitted to a referral hospital in Windhoek, Namibia. The findings indicate that some perceptions reflect biographical differences such as education, age and economic status. In some instances, perceptions of maternity clients were in line with findings published in existing literature that reported socio-economic circumstances and familial obligations which forced women to endure abuse. It was recommended that these differences in perceptions be taken into account during the counselling of maternity clients or while health education is being given.
\end{abstract}

\section{OPSOMMING}

Die doel van hierdie studie was om swanger vroue se persepsies in verband met gesinsgeweld verkennend te beskryf. 'n Kwantitatiewe, verkennende en beskrywende ontwerp is gebruik. Die studie was ook kontekstueel in ontwerp. Die populasie het uit swanger vroue bestaan wat in 'n verwysingshospitaal in Windhoek, Namibië, opgeneem is. Daar is bevind dat sommige persepsies deur biografiese veranderlikes bepaal word soos geletterdheidsvlak, ouderdom en ekonomiese status. In sekere gevalle is gevind dat die persepsies van swanger vroue ooreenstem met bevindinge in bestaande literatuur deurdat sosio-ekonomiese omstandighede en familieverpligtinge hulle dwing om gesinsgeweld te verduur. Daar word aanbeveel dat hierdie verskillende persepsies gedurende beradingsessies met swanger vroue of tydens gesondheidsopvoeding in ag geneem word. 


\section{INTRODUCTION AND BACKGROUND TO THE PROBLEM}

Pregnancy is a period of great anticipation and excitement for most women and their partners and families. Usually an expectant mother will pay greater attention to her own health during pregnancy, striving to avoid any harm, injury or deficiency in diet that could affect her unborn child. She will do everything in her capacity to ensure that her pregnancy reaches full term under circumstances that would allow optimum growth, health and development of her baby. The number of women who attend antenatal clinics (85\% attendance rate in Namibia) is a clear reflection of this level of care and concern, as is the fact that $75 \%$ of women attend health education sessions presented at clinics and deliver their babies in the hospital environment instead of at home (MOHSS, 2003b:119). Concern for the wellbeing of an expectant mother is usually shared by her partner and family, with all those involved working together to ensure the health of the mother and baby. Sadly, however, not all mothers experience ideal conditions. A variety of factors, over which the mother does not always have control, can endanger her own wellbeing or that of her child, or both. One such factor is domestic violence.

Once admitted to a health facility, pregnant women, including those who have been subjected to physical abuse, become classified as maternity clients. It is at this time that the researcher encounters them. As a registered midwife, the researcher admits and cares for these clients during the period immediately before delivery, during the process of delivery itself, and during the post-delivery period. Caregiving involves intimate contact with maternity clients, and entails physical and emotional assessment as part of routine nursing intervention.

\section{STATEMENT OF THE PROBLEM}

During the assessment of maternity clients, the researcher noticed that a number were in poor physical health. Some displayed bruising so extensive that it affected their health and that of their unborn child. The bruising observed appeared to be consistent with injuries associated with domestic violence (Johnson, 1989:681). These encounters led the researcher to suspect that these clients had been exposed to do- mestic violence.

Most cases of violence against women occur in the household. More than $20 \%$ of all cases of violence against women in Namibia occur within the context of domestic relationships. Statistically, more than 2000 cases of domestic violence are reported to the police annually (Hubbard, 1999:1). It was therefore possible that the bruises observed by the researcher could have been associated with domestic violence. However, not all cases of domestic violence (including those involving the abuse of pregnant women) are reported. The absence of what should be considered a normal response to abuse may be rooted in past experiences or belief systems which lead women to endure violence and not to report incidences of violence and abuse to the authorities.

The researcher concluded that an exploration and description of these perceptions and belief systems might help empower women who had suffered the humiliation and personal danger associated with domestic violence to take action and seek help. Findings might also equip nursing personnel to better help a maternity client who had endured domestic violence, and this might, in turn, support a positive change in her belief system.

An empowerment process could be integrated into an educational programme. Maternity clients should be informed about the personal danger inherent in violence during pregnancy, but should also become sensitised to the nature of domestic violence in general. This awareness would be of vital importance to the health of mothers and their unborn children, would develop the general knowledge of women with regard to their relationships, and would help women become more assertive in those relationships.

However, the perceptions of maternity clients concerning why women endure domestic violence are not known.

Owing to the highly sensitive nature of domestic violence, the researcher concluded that it would be necessary to approach maternity clients with sensitivity and discretion to ensure that they did not feel that they were being identified as victims of domestic violence. It would therefore be necessary to question maternity clients in a manner that framed their views in the context of hypothetical situations, not necessarily situa- 
tions in which they had personally been involved.

\section{RESEARCH PURPOSE}

In the context of the above considerations, the purpose of the study was to explore and describe the perceptions of maternity clients concerning domestic violence. More specifically, the objectives of the study were:

- to explore and describe the perceptions of maternity clients concerning why women endure domestic violence, and

- to describe and explore the perceptions of maternity clients concerning coping strategies they would use should they experience domestic violence.

\section{THE THEORETICAL FRAMEWORK}

For the purpose of this study the health belief model was used. The main components of this framework, which was deemed appropriate, relate to perceptions of benefits and barriers in health-seeking behaviour (Glanz, Lewis \& Rimer, 1997:46).

The selection of this framework was based on the researcher's observation that maternity clients who appeared to have been abused endured their ordeal and did not seek help to alleviate their situation (in other words, did not engage in health-seeking behaviour). In this regard, the health belief model is a value expectations theory in terms of which it is assumed that a person possesses a desire to avoid illness or to get well based on his or her belief that a specific health action is available that would prevent illness (expectancy). Expectancy can be further delineated in terms of an individual's personal estimate of susceptibility to an illness, of the severity of the illness (domestic violence), and of the likelihood of being able to reduce threat through personal action (Glanz et al. 1997:46). Beliefs about health, in particular the beliefs that one is susceptible to illness, that the consequences of disease could be serious, and that taking action results in greater benefit than cost, have been consistently associated with health behaviour (Wright, 1998:7). In addition, the health belief model incorporates components that make it possible to describe the situation of an abused person on several levels. These components are perceived susceptibility, perceived severity, perceived benefits, perceived barriers, cues to action and self- efficacy.

The ways in which women cope with and endure domestic violence should be analysed in terms of the components of the health belief model. It is assumed that people in general, and maternity clients in particular, will endure adversity if they perceive that some benefit will result from this "sacrifice". According to the health belief model, benefits accrue from taking action, not from inaction. By not taking action, the maternity clients observed thus appeared to act antithetically to the model. Their inaction appears to be the result of a conscious decision based on the belief that action will produce no beneficial result. A decision is also influenced by the perception of the seriousness of the situation, for instance the seriousness of domestic violence, and more specifically domestic violence during pregnancy (Glanz et al. 1997:47).

\section{LITERATURE REVIEW}

The aim of the literature review was to conduct research within a framework that encapsulated the focus of the study. As stated earlier, the researcher had noticed that maternity clients were being admitted with unexplained injuries, most alarmingly to the breasts and abdomen. These injuries indicated the possibility of exposure to domestic violence, and that, instead of reporting it, these women had in all likelihood endured and coped with their situation. The observed behavioural pattern indicated an embedded perception, a belief system that influenced action or inaction.

The health belief model was used to structure a review of the literature, and provided a methodological direction for the study.

Perceived susceptibility relates to an individual's perception of his or her risk of contracting a health condition (in this instance, being a victim of domestic violence). Pregnancy itself could be the catalyst for abuse if the father does not welcome the pregnancy or struggles to deal with the changes brought into his life arising from expectations accompanying the pregnancy. Gender roles may play a role in increasing the risk to which a woman is exposed. Statistically, more women than men are the victims of domestic violence. Gender roles are strongly defined by culture, and certain beliefs may condone domestic violence: examples are a 
belief that women are inferior and that a married woman is a chattel (WHO, 1996:10). Although there is not a specific personality type that is particularly susceptible to abuse, some beliefs may induce a woman to endure domestic violence, such as the belief that she "deserves" abuse or that the abuse is her fault. A socioeconomic, demographic factor that can be linked to domestic violence is substance abuse. A variety of studies conducted throughout the world (and in Namibia) reveal a strong link between the use of alcohol and domestic violence (David, 1989:34).

Perceived severity relates to perceptions concerning the seriousness of contracting an illness (being exposed to domestic violence). Perceived severity includes evaluation of both medical and clinical consequences, such as effect on work, family life and social relations (Glanz et al. 1997:47).

Domestic violence has serious physical and emotional implications for the health of a pregnant woman and her unborn child. It can cause physical conditions such as hypertension, gestational diabetes or almost any serious antepartum complication (Campbell \& Humphrey, 1993:156). Risks to the unborn child include low birthweight, premature birth and miscarriage (Lori, 1987:22). It is vital to inform women of the nature of these risks and their possible association with domestic violence.

Perceived benefits relate to one's perception of the efficacy of an advised action to reduce risk. They can also relate to the perception of the seriousness of a situation, for instance the possible danger emanating from domestic violence (Glanz et al. 1997:47). The adapted health belief model indicates the likelihood of action, meaning the likelihood that an abused woman will report an incidence of domestic violence, or that she will take action against her abuser. It is also an indicator of the perception as to whether any benefits will accrue from action. Benefits arising from domestic violence in Namibia are guaranteed by the Combating of Domestic Violence Act (Act No 4 of 2003) (Government of the Republic of Namibia, 2003). This comprehensive Act was promulgated in 2003 to protect and support victims of domestic violence. Thirteen woman and child protection units were established in Namibia to facilitate the implementation of the Act and also to provide support and care to women and children. Re- search has revealed that common-law practices in Namibia do not condone domestic violence, and that traditional leaders will take steps against a person who is guilty of domestic violence (Hubbard \& Wise, 1998:8). There are also religious organisations that reach out to the victims of domestic violence.

The component of perceived barriers relates to how an individual weighs the expected effectiveness of an action against the perception of how expensive, dangerous, unpleasant or inconvenient it may be (Glanz et al. 1997:47). Given the provisions of legislation created to protect them, why, then, do women endure domestic violence? Although the Namibian police are responsible for protecting citizens against this crime, women may believe that the guarantee of protection is not credible. Kitt and Kaiser (1990:623) explain this dilemma by stating that, historically, police officials have been trained to regard "family violence" as a domestic problem outside their jurisdiction, and best resolved through the intervention of social workers. Although the attitude of many male police officials may have changed, a woman experiencing abuse may fear that the official who responds to her distress call may not, in fact, protect her. A similar study indicates general dissatisfaction with the manner in which police deal with cases of domestic violence, based on the perception that male police officials believe women should be subservient to men (lipinge \& Le Beau, 1997:79).

Religious beliefs and practices may give women the strength to endure an illness or provide a source of hope (Urden, Stacey \& Lough, 2002:69). On the other hand, there is evidence that some women believe that their church congregation or church leaders will not always offer comfort and support in situations of domestic violence. In a study conducted by the Ministry of Health and Social Services of Namibia, it was discovered that many women believe that they will be regarded as "sinners" in the eyes of their congregation should they admit to being the victims of domestic violence (MOHSS, 2003a:48).

But why do women take no action? Hoff (1993:43) considers this question by referring to an all-encompassing environment in which women find themselves and to a commitment that most women carry with them. For women facing violence from their partner, domestic violence is not simply a matter that can be rectified by 
walking out the door. Women must consider and balance many issues: their children, their financial situation, alternative housing and personal safety.

Another component is cues to action, which refers to strategies that would activate readiness to take action or stimulate overt behaviour. The woman receives a cue to action or a precipitating force, as a result of which she perceives the need to take action. Strategies to activate readiness could take the form of providing information, promoting awareness or giving reminders. Although the Combating of Domestic Violence Act provides information on how to deal with abuse, studies have found that women do not always know their rights or how to exercise them.

The final component of the health belief model is selfefficacy, which can be defined as the belief that one can successfully carry out an action to produce a desired outcome. The lack of self-efficacy, or low selfesteem, is a perceived barrier to a recommended action against violence (Glanz et al. 1997:47). A woman must be empowered in order to have the capacity to take action. The psychological impact of domestic violence undermines the process of empowerment. In the short term, victims experience feelings of guilt, selfblame, sadness and anger (lipinge \& Hofnie, 2003:20). Over the long term, abused women describe altered identity, reflecting a changing self-concept and loss of self that results from the negative images that abusers reflect back to them. These women also identify a feeling of entrapment that reflects their loss of power (Wright, 1998:5). Some women believe they are coping with domestic violence by simply enduring the situation. Coping can be described as any action taken to manage stressors that tax an individual's resources (Johnson \& Maas, 1997:136). Coping serves two functions: the regulation of distress and the management of the problem that is causing the distress. Some women use ego defence mechanisms, such as rationalisation, to excuse their partner's behaviour, claiming, for example, that he is tired or overworked or that it is the alcohol he has consumed that makes him treat her that way, and that tomorrow everything will be normal again (Johnson, 1989:13).

\section{RESEARCH METHODOLOGY}

\section{Research design}

A quantitative, exploratory and descriptive design was utilised. The study was also contextual in design and quantitative in nature, as the data was quantified (Polit \& Hungler, 1997:153). As information was relatively scarce, the study was explorative (Babbie \& Mouton, 1998:79). Biographical data was collected to identify possible correlations between the perceptions of respondents and identifiable biographical indicators.

\section{Study population}

The sample population consisted of all maternity clients admitted to Windhoek Central Hospital during the 12-month period April 2004 to March 2005.

Maternity clients were approached during their recovery period in the postnatal ward. They were approached at this time on the assumption that they would be more relaxed following the delivery of their babies, and it was anticipated that they would consequently respond to the survey more freely and openly.

A total of 3084 maternity clients were admitted to the postnatal ward in 2003, and it was assumed that a similar number would be admitted during the period of the study. The projected estimated size of the population for the study was therefore in the region of 3000 .

\section{Criteria for inclusion and exclusion}

All women admitted to the maternity section of Windhoek Central Hospital who were willing to participate were included in the study. Participants were given a questionnaire to fill in. Those who required assistance in responding to questions posed in writing were interviewed, using the questionnaire as the basis for the interview. Respondents were assured of confidentiality.

\section{Sample and sampling technique}

To obtain a representative sample, it was statistically determined that questionnaires should be administered to at least 184 maternity clients. This number would ensure a confidence level of $95 \%$. A probability sampling method was used. The names of three months were selected at random to establish when data would be collected. During these three months clients were sampled only between Monday and Friday. The names 
of three clients were selected at random for exclusion from subsequent samplings. Each day, three clients were interviewed or filled in the questionnaire. The sample size on any given day was also influenced by the amount of time it took to interview an individual respondent, which was generally about 35 to 45 minutes. A total of 184 clients were interviewed, or filled in the questionnaire on their own, during the three months of the study.

\section{The research instrument}

A self-administered questionnaire consisting of openended and closed questions was used. This approach was chosen because it would ensure anonymity. In instances where participants required assistance, the researcher assured the respondents that no personal data would be recorded. The formulation of the questions was guided by the conceptual framework, namely an adaptation of the health belief model.

\section{Development of the instrument}

The questionnaire was developed in three stages:

- formulation of the questionnaire in line with the framework, an adaptation of the health belief model;

- testing of the questionnaire; and

- development of the instrument in line with the framework.

\section{Testing of the instrument}

Three methods were utilised to test the instrument, namely:

- $\quad$ testing for validity;

- $\quad$ testing for reliability; and

- a pilot study to test feasibility, resolve prob- lems related to the questionnaire, and test certain aspects of reliability.

The questionnaire was specifically tested for content validity. Content validity was ensured by a thorough review of the literature, by drawing on the informed opinion of a clinical nursing specialist in mental health, and by seeking the advice of the study leader who developed the questionnaire. Both consultants agreed on the relevance of the content.

\section{Reliability}

A specific measure of reliability is stability. Stability is the extent to which the same results can be obtained through repeated administrations of the instrument (Polit \& Hungler, 1997:387). For this study, stability was ensured by means of test-retest reliability: the questionnaire was administered on two different occasions to five participants who were not included in the pilot study. The information obtained was compared and it was noted that respondents provided the same information on each occasion.

\section{Pilot study}

A pilot study was conducted during the last week of March 2004 involving five women admitted to the maternity section of Windhoek Central Hospital who were not included in the main study. An aspect of the feasibility of the study, problem identification and the testing of reliability, was implemented. Only technical changes to the questionnaire were necessary at the end of the pilot study.

\section{Ethical issues}

Permission to carry out the study was granted by both the Ministry of Health and Social Services and the

Table 1: Questions and their relation to the framework

\begin{tabular}{|l|l|}
\hline Framework components & Question components \\
\hline Modifying factors & Biographical questions \\
\hline $\begin{array}{l}\text { Individual views/perceptions with } \\
\text { regard to likelihood of action }\end{array}$ & $\begin{array}{l}\text { Reasons for enduring domestic violence and inaction } \\
\text { Coping strategies where domestic violence is endured }\end{array}$ \\
& \\
\hline
\end{tabular}


maternity section of the hospital. The overall aim and objectives of the study were explained to prospective respondents, who were informed that their participation would be totally voluntary and that the care they received at the facility would not be influenced by whether or not they participated. The researcher explained that anonymity would be guaranteed and that names would not be recorded anywhere. Also, questionnaires would be collected in bulk to ensure that no information given on the instrument could be linked to any particular respondent. The process of data analysis was also explained to the respondents.

Because of the sensitive nature of the information gathered in the study, there was the possibility of respondents experiencing anxiety arising from their participation if the impression were given that a respondent had been identified as a victim of domestic violence. With this in mind, respondents were clearly informed that they had been selected to participate in the study not because they were suspected victims of domestic violence, but because their views and opinions were regarded as important. Oral consent was obtained from all respondents and no coercion whatsoever was used to achieve participation in the study.

\section{Data collection and analysis}

The study was prospective in nature, meaning that questionnaires were administered to respondents and inter- views were conducted with respondents only during their stay in the maternity ward during one of the three selected months. The researcher personally collected all 184 questionnaires distributed. Descriptive statistics were used and presented in the form of graphs as a means of identifying trends. Correlation statistics were also implemented.

\section{FINDINGS AND CONCLUSIONS}

Presentation of findings and conclusions was guided by the two objectives, the first of which related to the perceptions of maternity clients as to why women endured domestic violence.

For the nine items included to assess the validity of reasons why women tend to endure violence, a mean agreement of $60 \%$ was obtained. A non-agreement of $22 \%$ was obtained, meaning that $22 \%$ of respondents did not believe that the nine reasons were true or correct grounds for enduring domestic violence. Eighteen percent of respondents were not certain of the validity of the nine reasons included.

Figure 1 indicates responses to the nine items which the respondents indicated as being valid reasons for enduring domestic violence. Results demonstrate that 152 respondents $(82.5 \%)$ indicated that women tend to endure violence for the sake or benefit of their children.

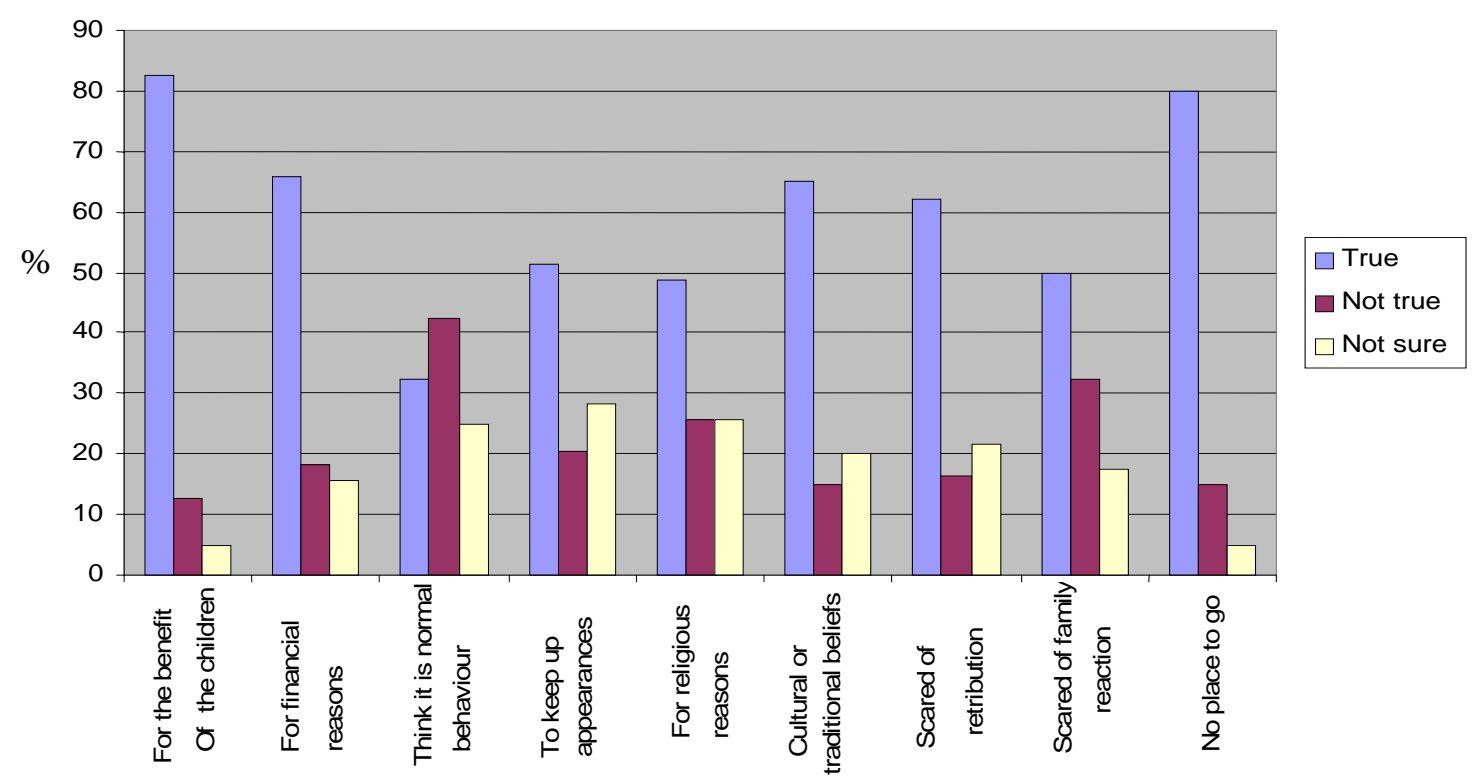

Reasons for enduring

Figure 1: Reasons for enduring domestic violence 
A woman's decision to remain in an abusive relationship appears to follow logically from the power disparity between women and men, and from cultural norms she has learnt concerning marriage, family and a woman's role as traditionally defined. It is commonly accepted that women have been charged with, and have largely accepted, the responsibility of holding families together in domestic tranquillity (Hoff, 1993:43).

Of the respondents, 147 (80\%) indicated that women tend to endure abusive relationships because they have nowhere else to go, as they are economically dependent on their partner. Economic dependence is cited by Nordien, Alpasan and Pretorius (2003:49) as one of several reasons why women remain in abusive marital relationships. A mother may also decide to remain in an abusive relationship because she believes that her children will benefit from the presence of an adult male. Another factor that plays a role is the rationalisation of the male partner's behaviour, attributing it to the use of alcohol at the time of a violent outburst. In other words, the male partner's drinking is identified as being to blame for the abusive behaviour, thus removing personal responsibility.

A significant relationship was discovered between languages spoken by the respondents and their views on why abused women endure domestic violence. In this study, the decision to remain in an abusive relationship based on religious grounds (see Figure 1) was correlated with language. Oshiwambo- and Afrikaans-speaking respondents agreed that women remain in an abusive relationship for religious reasons, while Hererospeaking respondents did not believe religion to be a reason $\left(\chi^{2}=25.790\right.$. $\left.P=0.004\right)$. It could be deduced that in the Namibian context a woman will endure domestic violence out of religious conviction, but only if she is Afrikaans or Oshiwambo speaking.

Most of the respondents in the study shared the view or perception that women endure domestic violence for the reasons indicated in Figure 1. This finding supports the views and perceptions identified in the literature.

Ten items in the questionnaire dealt with the perceptions of maternity clients concerning coping strategies they would implement in the event of domestic violence. These items, plus participants' responses, are presented in Figure 2. From this figure it can be seen that
$129(70 \%)$ of the respondents viewed approaching relatives as an appropriate coping mechanism when confronted with domestic violence.

The role of family support during situations of stress is discussed by Urden et al. (2002:69), who make the observation that family members are able to truly understand one another's experiences, even when little is said.

Of the respondents, 110 (60\%) regarded confiding in a medical practitioner as a coping strategy. It has been the researcher's personal observation that, in Namibia, medical practitioners are greatly respected and trusted by their clients. A significant correlation was discovered between property ownership and approaching a medical practitioner as a coping strategy. Respondents who were homeowners would consider approaching a medical practitioner when abused, whereas women who were not homeowners would not $\left(\chi^{2}=5.630 . \mathrm{P}=\right.$ 0.060 )

In this regard, the findings of this study do not, however, correlate with those of a study conducted by the Ministry of Health and Social Services of Namibia in 2003. The findings of that study indicated that only $10 \%$ of abused women would report an incidence of domestic violence to a medical practitioner (MOHSS, 2003a:47).

Of the respondents, 107 (58\%) indicated that they would contact "religious people" as a coping strategy. This finding corresponds to that of a report by Urden et al. (2002:69) indicating that beliefs and practices of a religious nature may provide people with a measure of acceptance of illness, and give them both hope and the strength to endure stress.

However, these results do not correspond to those of a study conducted by the Ministry of Health and Social Services in Namibia, which found that women who were exposed to domestic violence were not necessarily willing to approach religious people. The respondents in that study believed that an abused woman would be returned to her abuser, and regarded as a sinner in the eyes of the congregation (MOHSS, 2003a:48).

A significant relationship was also found between language spoken and going for a walk as a coping strat- 




Figure 2: Coping strategies

egy. Damara and Nama women identified taking a walk as a means of alleviating stress should their partner maltreat them, while the other respondents did not $\left(\chi^{2}\right.$ $=6.705 . P=0.035$ ).

A significant relationship was discovered between educational background and the willingness to approach a woman and child abuse centre for help. Respondents with an educational level below Grade 12 would tend not to approach such a centre, while respondents who had completed Grade 12 and had tertiary qualifications would $\left(\chi^{2}=22.231\right.$. $\left.P=0.014\right)$. This means that the respondents in this study with a higher educational level would be more inclined to approach an abuse centre for help.

Single respondents who owned property also indicated that they would not approach relatives if mistreated by their partner, while those who did not own property stated that they would definitely approach relatives $\left(\chi^{2}\right.$ $=6.705 . P=035$ ).

Being a Lutheran was also found to exert an influence on a woman's response to domestic violence. Lutheran respondents expressed a preference for reading the
Bible if they were abused $\left(\chi^{2}=15.534 . P=004\right)$. Turning to religion following abuse was confirmed as a response to domestic violence in a study by Rose-Junius, Tjapepua and De Witt (1998:65).

\section{RECOMMENDATIONS}

The findings of the present study indicate that some women perceived benefits, such as financial benefit, in enduring violence. Others believed that they would incur certain liabilities, primarily cultural or religious in nature, should they not be able to endure violence. Based on these findings, the following points should be addressed in educational programmes:

- $\quad$ an insight into health belief systems held by women regarding endurance; and

- the availability of response options for women who are subjected to domestic violence.

The ability to endure domestic violence also implies that women may employ a number of coping mechanisms simultaneously. In the health belief model, modifying factors are regarded as agents of change or survival strategies. During the creation of health education programmes, the following components should be con- 
sidered:

- the role of family support in coping with abuse;

- the role of woman and child abuse centres;

- the role of medical practitioners;

- aspects of self-esteem;

- personal empowerment, and the beneficial results of a lifelong learning process;

- the psychological effects of abuse; and

- the cycle of abuse.

Further research is indicated given the contradictory findings of this study and related research conducted in Namibia. Discrepancies may be explained in part by the fact that this was a contextual study whose target population was not representative of the general population.

\section{LIMITATIONS OF THE STUDY}

Ethically it was not possible to identify a conclusive link between the maternity clients sampled and status as victim of domestic violence. An investigative survey was conducted to determine whether such a link does exist, and to this end the views and perceptions of maternity clients, both those suspected of having been abused and those who were not, were collected and analysed. A quantitative approach was used. The researcher acknowledges that a triangulation of methods (qualitative and quantitative) might have provided more deeply insightful information. Finally, only a specific middle-class population was sampled: this population was thus not representative of a cross-section of maternity clients in Namibia.

\section{CONCLUDING SUMMARY}

Domestic violence is a disturbing reality within the Namibian population. Pregnant women (maternity clients) are not excluded from exposure to this kind of violence, making them, as well as their unborn children, susceptible to serious injury. It was observed that pregnant women suspected of being victims of this form of abuse appeared to endure and cope with it, despite the violence directed against them. Reasons why they took no action against their abusers were varied, but seemed embedded in belief systems linked to economic realities and traditional cultural practices. It is believed that if women have access to information about the subject, and also develop a greater sense of self-es- teem, they may be empowered to consider different options to deal with situations of domestic violence.

\section{REFERENCES}

BABBIE, E \& MOUTON, J 1998: The practice of social research. Cape Town: Oxford University Press.

CAMPBELL, J \& HUMPHREY, J 1993: Nursing care of survivors of family violence. London: Glen Myers.

DAVID, L 1989: Family violence in cross-cultural perspective. Frontiers of Anthropology. Volume 1. New York: Sage.

GLANZ, K; LEWIS, B \& RIMER, B 1997: Health behaviour and health education: Theory, research and practice. San Francisco: Jossey-Bass.

GOVERNMENT OF THE REPUBLIC OF NAMIBIA 2003: Government Gazette: Domestic Violence Act (No 4 of 2003). Windhoek: Government Printers.

HOFF, A 1993: Battered women as survivors. London: Mosby. HUBBARD, D 1999: Law reform and development commission. Windhoek: Legal Assistance Centre.

HUBBARD, D \& WISE, D 1998: Domestic violence: Proposal for law reform. Windhoek: Legal Assistance Centre.

IIPINGE, S \& HOFNIE, K 2003: Desk views of cases reported at the Woman and Child Protection Unit and subsequent course of action taken in Windhoek. Windhoek: University of Namibia Press. IIPINGE, U \& LE BEAU, D 1997: Beyond inequalities: Women in Namibia. Gender training and research programme. Windhoek: Pollinations.

JOHNSON, BS 1989: Psychiatric-mental health nursing: Adaptation and growth; $2^{\text {nd }}$ edition. Philadelphia: Lippincott.

JOHNSON, M \& MAAS, M 1997: Nursing outcome classification (NOC). St Louis: Mosby.

KITT, S \& KAISER, J 1990: Emergency nursing. A physiological and clinical perspective. London: WB Saunders.

LORI, H 1987: The health and development policy project. New York: Center for Disease Control.

MOHSS See MINISTRY OF HEALTH AND SOCIAL SERVICES NAMIBIA.

MINISTRY OF HEALTH AND SOCIAL SERVICES NAMIBIA 2003a: An assessment of the nature and consequences of intimate-male partner violence in Windhoek. Windhoek: Government Printers. MINISTRY OF HEALTH AND SOCIAL SERVICES NAMIBIA 2003b: Namibia demographic health survey 2000. Windhoek: Government Printers.

NORDIEN, R; ALPASAN, N \& PRETORIUS, B 2003: Muslim women's experience of domestic violence in Nelson Mandela Metropole: A qualitative study. Health SA Gesondheid, 8(4):38-55.

POLIT, D \& HUNGLER, B 1997: Nursing research. Principles and methods. Toronto: Lippincott. 
ROSE-JUNIUS, SMH; TJAPEPUA, VN \& DE WITT, J 1998: An investigation to assess the nature and incidence of spouse abuse in three sub-urban areas in the Karas region, Namibia. Windhoek: Pollinations.

URDEN, LD; STACEY, KM \& LOUGH, ME 2002: Thelan's critical care nursing. Diagnosis and management. London: Mosby. WHO See WORLD HEALTH ORGANIZATION.

WORLD HEALTH ORGANIZATION 1996: Violence against women. Geneva: WHO.

WRIGHT, RJ 1998: Exposure to violence. Available from: http:// www/macses.ucsf.Research/Psychosocial/notebook/ vilence.html (Accessed January 2005). 